\title{
HIGH PERFORMANCE CONCRETE - METHODS FOR PREPARATION, ADVANTAGES AND DRAWBACKS
}

\author{
Rahul Gangwar \\ Department of Civil Engineering \\ Bhagwant University, Ajmer (Rajasthan)
}

\begin{abstract}
High performance concrete provides high durability, strength, low water-cement ratio and longer life span of the structure. Special ingredients such as plasticizers, optimum aggregate size and fiber steel reinforcement are used to make this type of concrete admixture. This type of concrete type is used in special and complex construction structure such as bridges and tunnels. High performance concrete also helps in reducing the duration of the project, as there is low water cement ratio in making the admixture for the concrete. This type of concrete is useful for fast track construction where owner required the possession of the property as soon as possible. High performance concrete has several advantages over traditional Portland cement concrete.
\end{abstract}

Keywords- plasticizers, Portland cement, Specific Density, Admixtures

\section{INTRODUCTION}

First, high performance concrete provides better strength and durability. Water cement ratio majorly affects the workability of the concrete (Naik et. al., 2012). According to Naik et al., (2012, p. 463), increase in the water cement ratio, which can be obtained by increasing the water content in the concrete admixture, increases the workability and slump ratio of the concrete.

According to Kudar, Leman, Berman, Hannesson, and Shogren et al(2012, p. 285), concrete has gained significant importance in the construction industry because it is a versatile, available, and cost effective material. However, Naik, Kumar, Ramme, and Canpolat et al(2012, p. 463) stated that concrete has not remained a material only composed of cement, commonly Portland cement, aggregate, and ware during the last two decades, and it has changed to a material with various new constituents to satisfy the construction requirements. High performance concrete is a type of regular Portland cement concrete. Excessive water in the concrete admixture can reduce the strength of the concrete and durability. To maintain the water cement ratio and increase the strength, plasticizers are used to increase the bonding between the particles of the Portland cement. Moreover, high performance concrete has a discontinuous pore structure that reduces liquid ingress and permeability, which leads to significantly enhanced durability, longer service life and lower cost for maintenance (Wan et al., 2015). However, in the case of construction in summer time, there are more chances of failure and cracking in the structure. The heat factor plays an important role in the curing of the concrete. At this situation, more water is required for curing of the concrete. Adding more water for curing may increase the water cement ratio in the concrete admixture resulting in less permeability of concrete. According to Guneyisi, Gesoglu, and Ozbay et al(2010, p. 1878), concrete shrinks due to the tensile stresses produced by the loss of water, which is known as drying shrinkage of concrete. Therefore, temperature in summer construction can create problem of loss of water resulting in shrinkage of the concrete. Dry shrinkage of the concrete leads to cracking and failure of structure at early age.

Second, high performance concrete can help in making sustainable construction in larger project making more environments friendly. Even though cement has less impact on environment than steel but still it produces 5\% greenhouse gases worldwide. According to Fouad et al., (2014, p. 3) high performance concrete will address sustainability by introducing strategies for reducing Portland cement in concrete, improving concrete's performance by using less material, and making it more durable in order to increase its lifespan with minimum maintenance costs. Therefore, Ultra high performance concrete will help in minimizing the overall cost of the project as well as it will help in making construction sustainable, which environment 


\section{International Journal of Engineering Applied Sciences and Technology, 2020 Vol. 4, Issue 11, ISSN No. 2455-2143, Pages 639-643 \\ Published Online March 2020 in IJEAST (http://www.ijeast.com)}

friendly is producing less greenhouse gas. High performance concrete is a milestone in the process of addressing sustainability in the concrete industry for contractors and subcontractors out in the market (Fouad et al., 2013, p. 9). Fly ash and silica fumes also plays important role for high performance concrete admixtures, these ingredients help in improving the strength and durability of the concrete. Low water cement ratio with fly ash or silica fumes improves the durability and reduces the cost of construction. These ingredients are environment friendly and help in creating sustainable construction. Furthermore, mineral admixtures are generally industrial wastes or by- products, disposal of these industrial by-product materials could be a source of economic loss and a problem with respect to environmental and health issues (Uysal ans sumer, 2011).

According to Uysal et al (2012, p. 264), one of the global environmental problems is the disposal of the by-products of the marble industry, MP, composed of extremely fine powders.

However, as commonly known, sector of building materials is the third largest $\mathrm{CO} 2$ emitting industrial sector world-wide, as well as in the European Union. According to Spiesz et al. (2014, p. 1) the cement production is said to represent $7 \%$ of the total anthropogenic $\mathrm{CO} 2$ emission. Hence, one of the key sustainable challenges for the next decades is to design and produce high performance concrete with less clinker and inducing lower $\mathrm{CO} 2$ emission than traditional one, while providing the same reliability and better durability.

Moreover, the sustainability of materials is related to their life stages, production of components, construction, life cycle, and demolition. (Fouad et al., 2013, p. 4). According to Fouad et al., (2013, p. 9), the mineral course will emphasize the importance of each stage for increasing the sustainability of concrete, thus sustainability will be approach from two perspectives: materials and structural design. Construction of a structure with high performance concrete leads to several advantages in construction industry. However, high performance concrete contains some environmental drawbacks also such as emission of $\mathrm{CO} 2$, greenhouse gases, and recycling of the minerals. High performance concrete contains some minerals and plasticizers admixtures which show adverse effects to the environment upon demolition of the building.
Third, high performance concrete has large percentage of silica fume and fly ash particles, which are 100 times smaller than traditional Portland cement. According to Fouad et al. (2014, p. 5), silica fume increases the compressive and tensile strength and durability of concrete significantly. The author says, it's extremely fine particles fill the microscopic voids between cement particles. Other advantages of applying silica fume to concrete include increased bond strength between aggregate and paste, providing superior resistance to chemical attacks, increases abrasion resistance, reduced permeability and less expansion than traditional concrete (Fouad et al., 2014, p. 5). Moreover, high performance concrete can be made more economical by using local recyclable materials as transportation cost of steel and admixture and high.

According to Burkhart et al (2016, p. 130), the present work focuses on developing high performance concrete mixture using local materials so that HPC may be made more affordable to wide variety of construction applications. The final high performance concrete mix design consisted of dolomite coarse aggregates $(1.18 \mathrm{~mm})$, manufactures sand, known as man sand, which is crushed from limestone with a size of $0.105 \mathrm{~mm}-0.60 \mathrm{~mm}$, type I/II cement, silica fume, recyclable concrete aggregates to match size of coarse aggregates, and HRWRA were used and all were available from locally available providers within 50miles radius (Burkhart et al 2016, p. 130)

\section{LIERATURE REVIEW}

The literature review shows that, water-cement ratio, silica fume, plasticizers accelerate the strength of the concrete. Concrete is the most versatile material in the construction industry. Concrete admixture can be made using several ingredients in which ordinary Portland cement is the basic ingredient. Over the period of time and technology many ingredients have been used to make concrete admixture more workable and capable of bearing tensile as well as compressive strength. High performance concrete is one the special type of concrete admixture used in recent day construction to increase the strength of the structure. The special parameters used in the high performance concrete are plasticizers, fly ash and silica fumes in addition to regular water cement ratio, aggregates and sand. The use of fly ash fills the voids between the cement particles and helps it to make admixture more strength resistant. The particles of fly ash are smaller than Portland cement because of which they occupy space and fill the voids. Plasticizers are used to increase the strength of the 


\section{International Journal of Engineering Applied Sciences and Technology, 2020 \\ Vol. 4, Issue 11, ISSN No. 2455-2143, Pages 639-643 \\ Published Online March 2020 in IJEAST (http://www.ijeast.com)}

concrete after initial settlement and curing of the concrete. Plasticizers are used to accelerate the curing period of the concrete and admixture gains more strength with first 7 days of curing period. Therefore, special admixtures can be used in ordinary Portland cement to optimize the workability and strength of concrete, decrease the curing period and dry shrinkage of concrete.

Special admixture like fly ash and silica fume can be used to replace the mineral admixtures to increase the workability and strength of the concrete in order to create high performance concrete. According to Fouad et al. (2014, p. 6), "small particles of fly ash make the concrete more cohesive and prevent segregation and bleeding." High percentage use of fly ash increases the set time of concrete and slow development of strength. This setting time of concrete admixture can be reduced by introducing the plasticizers in the admixture. Plasticizers also accelerate the strength gaining process of mixture. However, introduction of plasticizers increases the cost of concrete significantly. On the other hand, by replacing cement $100 \%$ to fly ash-based hydraulic binder produces green concrete (zero carbon emission). Green concrete made of fly ash-hydraulic binder can accelerate the mechanical as well as conventional properties of cement. Green concrete serves higher workability and strength than traditional ordinary Portland cement concrete. Fly ash can be used as special ingredient to make concrete mixture green and increase the strength and mechanical properties of the concrete.

\section{EXPERIMENTAL WORK}

Yu et al. (2014, p. 2) experimented on different type of admixtures that can be used in high performance concrete and calculated the density of the concrete as shown in table 1.

\begin{tabular}{|c|c|c|}
\hline$\underline{\text { Materials }}$ & Type & $\frac{\text { Specific Density }}{(\mathrm{kg} / \mathrm{Cu} . \mathrm{m})}$ \\
\hline Cement & CEM I $52.5 \mathrm{R}$ & 3150 \\
\hline Filler-1 & Limestone & 2710 \\
\hline Filler-2 & Quartz & 2660 \\
\hline Fine sand & Micro sand & 2720 \\
\hline Coarse sand & Sand 0-2 & 2640 \\
\hline Silica fume & Micro-Silica & 2200 \\
\hline $\begin{array}{l}\text { Super } \\
\text { plasticizer }\end{array}$ & $\begin{array}{l}\text { Polycarboxylate } \\
\text { ether }\end{array}$ & 1050 \\
\hline Fiber & Steel Fiber & 7800 \\
\hline
\end{tabular}

According to table 1, they (Yu et al.) concluded that, super plasticizers have lowest specific density and give maximum strength to the concrete admixture. From table, cement has maximum specific density followed by limestone, coarse sand. Conventional Portland cement concrete is made with Portland cement, sand and coarse sand (aggregates), which increases the specific density of the concrete. However, high performance concrete is made with cement, fly ash and plasticizers which decrease the specific density of the concrete admixture resulting in highest possible strength of the concrete.

Portland cement, coarse and fine sand can be replaced with plasticizers to accelerate the strength gaining process of admixture and reduce the initial setting time of concrete. According to Regd et al., (2015, p. 22), super plasticizers are also known as 'high range water reducer'. The author says, the use of super plasticizers permits the reduction of water to the extent up to 30 percent without reducing workability in contrast to the possible reduction up to 15 percent in the case of plasticizers. The experiments have been conducted on strength gaining of concrete admixture, and it was found that, high performance concrete admixture gains maximum strength in initial settlement time. Conventional Portland cement concrete admixture gains approximately $2 / 3$ rd of strength within its 7 day curing period. However, it has been observed that, high performance concrete admixture gains more than $2 / 3 \mathrm{rd}$ of its final strength within 7 day curing period. Moreover, plasticizers reduce the water content in the admixture and accelerate the bonding process in the concrete. Regd et al., (2015, p. 22), conducted an experiment on strength gained by concrete in its initial settlement period and found results as shown in table 2 .

\section{Classification}

Ordinary normal concrete

Standard normal concrete

High performance concrete

Very high performance concrete

Exceptional Concrete

Table 2. Valid Classification of High Performance Concrete (Regd et al., 2015, p. 22)

According to table 2, they (Regd, et al.) concluded that by introduction of super plasticizers in concrete 


\section{International Journal of Engineering Applied Sciences and Technology, 2020 Vol. 4, Issue 11, ISSN No. 2455-2143, Pages 639-643 \\ Published Online March 2020 in IJEAST (http://www.ijeast.com)}

admixture accelerates the strength gaining process of concrete and give maximum possible result. Plasticizers reduces the water content in the concrete admixture and it starts gaining the strength, whereas super plasticizer further reduces the water content to attain strength up to $150 \mathrm{Mpa}$ at 28 day curing period. The use of super plasticizers makes concrete admixture very high performance concrete. Kim et al., (2013, p. 727), performed experiment on ultrahigh performance concrete with super plasticizer and used it in construction on hybrid cable-stayed bridge. The author found that, after final setting time of concrete, it gained $200 \mathrm{Mpa}$ of strength, which is three times the standard Portland cement concrete. This observation shows that ultra-high performance concrete can be used in heavy construction to obtain maximum strength.

Portland cement concrete can be replaced with quartz and silica fume in high performance concrete to make concrete sustainable and reduce the dry shrinkage of the concrete.

Conventional Portland cement concrete contains coarse aggregates and sand, which does not fill the voids between cement and aggregates. These void results in dry shrinkage of concrete when the water cement ratio in admixture is reduce with plasticizers to make it high performance. Dry shrinkage of concrete leads to cracking and failure at the initial settlement time period. Quartz and silica fumes are highly chemical resistant, which makes them sustainable and reduces the $\mathrm{CO} 2$ emission. According to Patel et al., (2013, p. 70), concrete mixture containing $15 \%$ natural pozzolan, and $15 \%$ silica fume shows the best protection in sulphates solution and sea water by retaining $65 \%$ of its compressive strength. The author also believes that, high performance concrete two-way slab with M60 grade concrete with W/C ratio $0.32 \%$ and $7.5 \%$ silica fume exhibit good strength then reinforced cement concrete. Fly ash and silica fume helps in filling the voids between cement particles and coarse aggregates, which reduces the chances of dry shrinkage considerably. The dry shrinkage was observed in conventional Portland cement concrete, which is minor at initial setting time but increases as concrete admixture starts gaining strength with curing period. Guneyisi et al., (2010, p. 1883) stated that replacing Portland cement by FA, GBFS, or MK remarkably reduces the high performance concrete drying shrinkage at water cement ratio of 0.32 .
However, Kang et al., (2015, p. 355), conducted experiment on difference between high performance concrete and conventional concrete in construction of girder. The author observed that, specimen with rough interface could not develop perfectly composite behavior and experienced adhesive failure.

Kang, et al., observed that high performance concrete behaves better in curing and strength gaining process than conventional Portland cement concrete. The author advices to use smooth wooden plank surface to install the girder with high performance concrete.

\section{CONCLUSION}

In conclusion, special admixtures can be used in ordinary Portland cement to optimize the workability and strength of concrete, decrease the curing period and dry shrinkage of concrete. Special admixture like fly ash and silica fume can be used to replace the mineral admixtures to increase the workability and strength of the concrete in order to create high performance concrete. Portland cement, coarse and fine sand can be replaced with plasticizers to accelerate the strength gaining process of admixture and reduce the initial setting time of concrete. Portland cement concrete can be replaced with quartz and silica fume in high performance concrete to make concrete sustainable and reduce the dry shrinkage of the concrete. High performance concrete is a replacement over conventional Portland cement concrete to give more strength to structures. Strength gaining process of high performance concrete can be increased using the plasticizers and super plasticizers. The lower the water cement ratio, the higher is the strength gained by admixture at 28days curing period. Fly ash and silica fumes are important replacement for Portland cement minerals to fill the voids between cement particles and coarse aggregates, which increase the strength of the concrete and reduce the dry shrinkage failure. The strength gained by high performance concrete in initial setting time is more than Portland cement concrete. The super plasticizers in concrete admixture reduce the water content and help to gain the strength at initial setting time. High performance concrete is a crucial replacement for Portland cement concrete for major construction site such as tunnel, bridge and highway roads. The durability of the high performance concrete is longer than Portland cement. High performance concrete gives longer life span to girders, columns and slabs. The dry shrinkage of high performance concrete is lower than Portland cement concrete because fly ash fills the voids between coarse aggregates and cement particles. High performance concrete is also known as green 


\section{International Journal of Engineering Applied Sciences and Technology, 2020 \\ Vol. 4, Issue 11, ISSN No. 2455-2143, Pages 639-643 \\ Published Online March 2020 in IJEAST (http://www.ijeast.com)}

concrete. The volume of $\mathrm{CO} 2$ emitted by HPC is lower than Portland cement concrete. High performance concrete can be used to make sustainable admixture. Hence, high performance concrete is a better replacement over traditional Portland cement concrete.

\section{ACKNOWLEDGEMENTS}

The authors are grateful to the individuals who were involved with this project and provided invaluable assistance. The presenters sincerely thank the authorities of Bhagwant University, Ajmer (Rajasthan), and Gawar Constructions for smoothly conducting these tests in the laboratory of concrete lab and construction sites.

\section{REFERENCES}

1. Fouad, F. H. (2014). Emphasizing sustainability in a course on reinforced concrete design.

American Society of Engineering Education

2. Guneyisi, E., Gesoglu, M., \& Oxbay, E. (2010). Strength and drying shrinkage of self- compacting concretes incorporating multi-system blended mineral admixtures. Construction and Building Materials, 24, 1878-1887.

3. Kang, J. Y., Park, J. S., Jung, W. T., \& Keum, M. S. (2015). Connection between Concrete Layers with Different Strengths. Engineering, 7, 365-372. http://dx.doi.org/10.4236/eng.2015.77032

4. Kim, H. S., Kim, Y. J., Chin, W. J., \& Yoon, H. (2013). Development of Optimal structure system for hybrid cable-stayed bridges using ultra high performance concrete. Engineering, 5, 720-728. http://dx.doi.org/10.4236/eng.2013.59086.

5. Kuder, K., Lehman, D., Berman, L., Hannesson, G., \& Shogren, R. (2012). Mechanical properties of self-consolidating concrete blended with high volumes of fly ash and slag. Construction and Building Materials, 34, 285-295.

6. Naik, T. R., Kumar, R., Ramme, B. W., \& Canpolat, F. (2012). Development of highstrengh, economical self-consolidating concrete. Construction and Building Materials, 30, 463- 469.

7. Patel, V., \& Shah, N. (2013). A survey of high performance concrete developments in civil engineering field. Open Journal of Civil Engineering, 3, 69-79. http://dx.doi.org/10.4236/ojce.2013.32007

8. Regd, E. G., MNSE, Lond, I., Lond, I., \& Okoye, S. S. (2015). Relevance of high performance concrete applications in modern civil engineering construction. International Research Journal of Engineering Science, Technology and Innovation. 4, 19-24.

Doi: http://dx.doi.org/10.14303/irjesti.2014.083

9. Torres, A., \& Burkhart, A. (2016). Developing sustainable high strength concrete mixtures using local materials and recyclable concrete. Material Sciences and Applications, $\quad 7, \quad 128-137$. http://dx.doi.org/10.4236/msa.2016.72013

10. Uysal, M., Yilmaz, K., \& Ipek, M. (2012). The effect of mineral admixtures on mechanical properties, chloride ion permeability and impermeability of selfcompacting concrete. Construction and Building Materials, 27, 263-270.

11. Uysal. M., \& Sumer. M. (2011). Performance of self-compacting concrete containing different mineral admixtures. Construction and Building Materials, 29, 7381.

12. Wan, L., Wendner, R., Liang, B., \& Cusatis, G. (2015). Experimental and Computational analysis of the behavior of ultra-high performance concrete at early age. Cement and Concrete Composite. Arxiv:1509.07801v1

13. Yu, R., Spiesz, P., \& Brouwers, H. J. H. (2014). Mix design and properties assessment of ultra-high performance fibre reinforced concrete (UHPFRC). Cement and Concrete Research. 56, 29-39. http://dx.doi.org/10.1016/j.cemconres.2013. 11.002 